\begin{tabular}{|c|c|c|c|}
\hline Article Info & \multicolumn{2}{|c|}{\begin{tabular}{l|l} 
REVIEW ARTICLE & DERLEME MAKALESİ
\end{tabular}} & \\
\hline Title of Article & \multicolumn{2}{|c|}{$\begin{array}{l}\text { Potential Impacts of the Covid-19 } \\
\text { Outbreak on Urban Quality of Life: The } \\
\text { Case of China }\end{array}$} & \\
\hline $\begin{array}{l}\text { Corresponding } \\
\text { Author }\end{array}$ & \multicolumn{2}{|c|}{$\begin{array}{l}\text { Çile MADEN KALKAN } \\
\text { Ankara Hacı Bayram Veli Üniversitesi, Edebiyat Fakültesi, Lisansüstü Eğitim Enstitüsü, } \\
\text { Doğu Dilleri ve Edebiyatları Bölümü, Çin Dili ve Edebiyatı ABD, cile.maden @hbv.edu.tr }\end{array}$} & \\
\hline $\begin{array}{l}\text { Received Date } \\
\text { Accepted Date }\end{array}$ & \multicolumn{2}{|l|}{$\begin{array}{l}13.09 .2021 \\
21.12 .2021\end{array}$} & \\
\hline DOI Number & \multicolumn{2}{|c|}{ https://doi.org/10.35674/kent.994920 } & \\
\hline Author / Authors & $\begin{array}{l}\text { Çile MADEN KALKAN } \\
\text { Aylin YILMAZ ŞAŞMAZ }\end{array}$ & $\begin{array}{l}\text { ORCID: 0000-0003-4736-7101 } \\
\text { ORCID: 0000-0001-7863-4140 }\end{array}$ & \\
\hline How to Cite & \multicolumn{2}{|c|}{$\begin{array}{l}\text { MADEN KALKAN, Ç. and YILMAZ ŞAŞMAZ, A. (2021). Covid-19 Salgınının Kentsel } \\
\text { Yaşam Kalitesi Açısından Potansiyel Etkileri: Çin Örneği, Kent Akademisi, Volume, } \\
\text { 14, Issue 4, 1283-1298 }\end{array}$} & $\begin{array}{l}\text { Kent Akademisi } \\
\text { Urban Academy }\end{array}$ \\
\hline
\end{tabular}

\title{
Covid-19 Salgınının Kentsel Yaşam Kalitesi Açısından Potansiyel Etkileri: Çin Örneği
}

Çile MADEN KALKAN ${ }^{1}$ Aylin YILMAZ ŞAŞMAZ ${ }^{2}$

\begin{abstract}
:
As we move towards 2022, our world still has not fully recovered from the Covid-19 epidemic. This epidemic has changed both people and the world in terms of quality of life. Many countries and cities in the world have almost entered "sleep mode" due to the restriction policies brought by the pandemic. Pandemic restrictions have caused great damage to China, especially to the country's economy. On the other hand, the pandemic has had a positive effect by allowing the blue sky to be seen in China, which has been complaining about air pollution for years. In the effect of the process on people under the name of social life, there are two types of human diversity as producing and consuming. People focused more on their homes and families, and they started production by finding new occupations for themselves as a psychological treatment. On the other hand, these restrictions have disrupted the psychology of some people and pushed them to become consumers only. In other words, it is possible to say that the pandemic has had both positive and negative consequences on the quality of life. The aim of this study is to address the effects of human mobility restrictions caused by the Covid-19 pandemic on economy, social life, and environment throughout China. For this purpose, CNKI database and information obtained from open sources were used in the article. In this direction, it has been concluded that the pandemic in China generally affects the economy negatively, the environment generally positively, and human life both positively and negatively.
\end{abstract}

\footnotetext{
${ }^{1}$ Ankara Haci Bayram Veli University, Faculty of Letters, Institute of Graduate Programs, Department of Eastern Languages and Literatures, Chinese Language and Literature, cile.maden@hbv.edu.tr

${ }^{2}$ Ankara Haci Bayram Veli University, Faculty of Letters, Institute of Graduate Programs, Department of Eastern Languages and Literatures, Chinese Language and Literature, aylin.yilmaz@hbv.edu.tr
} 
KEYWORDS: Covid-19 Pandemic, China, Economy, Quality of Life, Social Life, Environment.

ÖZ:

2022 yılına doğru ilerlerken, dünya Covid-19 salgınından hala tam olarak kurtulabilmiş değildir. Bu salgın hastalık hem insanları hem de dünyayı yaşam kalitesi açısından değiştirmiştir. Dünyada çok sayıda ülke ve şehir, pandeminin getirmiş olduğu kısıtlama politikaları nedeniyle adeta "uyku moduna" girmiştir. Pandemi kısıtlamaları Çin'de özellikle ulaşım, ticaret, turizm vb. alanları olumsuz yönden etkileyerek, ülkenin ekonomisine büyük zararlar vermiş̧ir. Ekonominin zarar görmesi ise doğal olarak ülkede yaşayan bütün insanları, nakit para akışını zora sokmuştur. Diğer yandan pandemi, hava kirliliğinden yıllardır yakınan Çin'de mavi gökyüzünün görülmesine olanak sağlayarak, olumlu bir etki yaratmıştır. Havanın yanı sıra toplu yaşam alanlarındaki gürültü ve çevre kirliliği azalmış, sahiller daha temiz duruma gelmiş, kısacası doğa olumlu anlamda kendini yenileme sürecine girmiştir. Sürecin sosyal yaşam adı altında insanlar üzerindeki etkisinde ise kabaca üreten ve tüketen olarak iki tip insan çeşitliliği oluşmuştur. İnsanlar sokağa çıkma kısıtlamalarında evlerine ve ailelerine daha fazla odaklanmış, psikolojik bir tedavi olarak kendilerine yeni uğraşlar bularak üretime geçmişlerdir. Öte yandan bu kısıtlamalar bazı insanların psikolojisini bozarak onları sadece tüketici olmaya itmiştir. Yani bu doğrultuda pandeminin yaşam kalitesi üzerinde hem olumlu hem de olumsuz sonuçları olmuştur demek mümkündür. Bu çalışmanın amacı Covid-19 pandemisinden kaynaklı insan hareketliliği kısıtlamalarının Çin genelinde ekonomik, sosyal yaşam ve çevre üzerindeki etkilerini ele almaktır. $\mathrm{Bu}$ amaca uygun şekilde makalede China Academic Journals (CNKI) veri tabanı ve açık kaynaklardan elde edilen bilgiler kullanılarak, Covid-19 pandemisinin Çin'deki olumlu-olumsuz etkileri sosyal bilimler çerçevesi içinde incelenmiştir. Bu doğrultuda Çin'de pandeminin özellikle ekonomiyi genellikle olumsuz yönde, çevreyi genellikle olumlu yönde ve insan yaşamını ise hem olumlu hem de olumsuz yönde etkilediği sonucuna varılmıştır.

ANAHTAR KELIMELER: Covid-19 Salgını, Çin, Ekonomi, Yaşam Kalitesi, Sosyal Yaşam, Çevre.

\section{“Covid-19 Salgınının Kentsel Yaşam Kalitesi Açısından Potansiyel Etkileri: Çin Örneği”}

\section{GíRiş:}

Dünyada artan nüfus ile birlikte, insanların büyük bir bölümü de kentlerde yaşamaya başlamıştır. Bu durum kentsel yaşam kalitesi konusunu küreselleşmenin güncel sorunlarından biri haline getirmiştir (Marans, 2007). Kentsel yaşam kalitesi, net veya uzlaşılmış tanımı olan basit bir terim değil, çeşitli disiplinler tarafından tanımlanabilecek karmaşık bir kavramdır. Kentsel yaşam kalitesi terimi, bazı fiziksel özellikleri tanımlamak için değil, bu fiziksel özellikler arasındaki tüm ilişkiyi, dinamikleri ve "ağ” benzeri ilişkiyi tanımlamak için kullanılmaktadır. Bu nedenle de kentsel yaşam kalitesi tanımı, doğrusal ve temel olmaktan ziyade karmaşıtır.

Bu çok disiplinli kavramı tanımlamak için onu daha kesin terimlere ayırmak ve bu terimler arasındaki ilişkiyi bulmak gerekmektedir. Öncelikle, "kalite" kelimesi, bir ürünün çekiciliğini veya mükemmelliğini belirtmek için sıklıkla kullanılmaktadır. "Yaşam kalitesi" ise son yıllarda büyük ilgi uyandıran bir kavram olmakla birlikte, yalnızca yirminci yüzyılın kavramı değildir. Bu kavram, "iyi hayat", "iyi yaşamak" ve bunun kamu politikalarıyla beslenmesine nasıl yardımcı olunabileceği hakkında eserler yazan Aristoteles (MÖ 384-322) gibi filozoflara kadar uzanmaktadır. 1889 yılında ise yaşam kalitesi kavramı araştırmacı Seth tarafından: "Ahlaki sonu oluşturan "yaşam” "ın yalnızca niceliğini değil, aynı zamanda niteliğini de dikkate almalıyı (Marshall \& Banister, 2007)" şeklinde yapılan bir açıklamada kullanılmıştır. Bundan sonra yaşam kalitesi birçok çalışmanın odak noktası olmuş, ancak nasıl tanımlanması gerektiği konusunda bir fikir birliğine varılamamıştır.

Yaşam kalitesi, farklı teorik perspektiflerden çoklu yaklaşımlar gerektiren karmaşık, çok boyutlu bir yapıdır. Farklı disiplinlerde yaşam kalitesini neyin oluşturduğunu tanımlamaya yönelik birçok girişimde bulunulmuştur. Literatürde yüzden fazla yaşam kalitesi tanımı yapılmaktadır. Örneğin yaşam kalitesi; "paradan çok, iyi sağlık, rahatlık, iyi ilişkiler vb. anlamlara geldiği gibi, yaşanılan kültürel veya entelektüel koşullardan kişisel memnuniyet veya memnuniyetsizlik (The Free Dictionary, 2012)" olarak da tanımlanabilmektedir.

Yaşam kalitesi, sağlıklı beslenme, temiz hava ve su, sınırsız açık alanların keyfi, yaban hayatı ve doğal kaynakların korunması, suçtan korunma, radyasyon ve toksik maddelerden korunma ile zenginleştirilmiş günlük yaşamı ifade 
etmektedir. Aynı zamanda, bir kişinin sahip olduğu engellerden bağımsız olarak, hayattan zevk almasını ve hayatın zorluklarının üstesinden gelmesini sağlayan enerji ve gücün bir ölçüsü olarak da kullanılabilmektedir. 1960'lardan itibaren, bilim insanlarınca birçok konuyu içeren "yaşam kalitesi” kavramı 90'lı yıllardan itibaren sosyologlar tarafından da araştırmalarda kullanılmaya başlanmıștır. Hatta alanda yapılan çalıșmalar sayesinde hızlı ve çarpık kentleşmenin yaşam kalitesini etkilediğinin tespit edilmesi, "kent" ve "yaşam kalitesi" kavramlarının birlikte ele alınması konusunu gündeme getirmiştir (Görün \& Kara, 2010: 143).

Tüm dünyada başgösteren pandemi süreci de sosyal bilimler içerisinde kentsel yaşam kalitesi kavramı ile bağdaştırılıp ele alınabilmektedir. Bu sürecin ekonomi, sosyal yaşam ve çevre faktörleri açısından ele alınması, kentsel yaşam kalitesinin incelenmesine de olanak sağlamaktadır. Kısacası insan ve doğa ayrımı olmaksızın birçok disiplini kapsayan kentsel yaşam kalitesini, pandemiler, ekonomik krizler, doğal afetler ve insanların bu sorunlara karşı duruşları da etkilemektedir. 2019 yılının Aralık ayının başından bu yana Çin'in Hubei (湖北) Eyaleti'nin başkenti Wuhan'da (武汉) birçok viral zatürre vakası bulunmuş ve bunun daha sonra yeni bir tür virüsün neden olduğu yeni bir hastalık olduğu doğrulanmıştır. Dünya Sağlık Örgütü (WHO), insandan insana bulaşma özelliğine sahip olduğu doğrulanan bu yeni virüsü, 11 Şubat 2020 tarihinde, resmi olarak "korona virüs hastalığı 2019 (Covid-19)" olarak adlandırmıştır.

Covid-19 için başta Çin ve Almanya olmak üzere bazı ülkeler koruyucu nitelikte aşılar üretmişlerdir, ancak hastalığın tam olarak ortadan kaldırılması adına henüz tam bir aşı bulunamamıştır. Hastalığın insandan insana hızlı bir şekilde bulaşması, her bünyede farklı tepkiler vermesi ve hatta son dönemlerde mutasyona uğrayarak farklı varyantlarının çıkması da net bir aşının geliştirilmesinde sorun yaratmaktadır. Durum böyle olunca ülkeler hastalığın seyrini hafifletmek için yapılan aşıların yanı sıra belirli karantina politikaları da uygulamak zorunda kalmışlardır. Bunlar arasında en yaygın olanları ülke sınırlarını, hava, kara, deniz ve tren yollarını belirli ölçülerde kapatmak, ülke içi dolaşımı kısıtlamak ve hatta sokağa çıkma yasakları koymakdır.

Covid-19 hastalığı kadar, kapanma politikaları gereği uygulanan kısıtlamalar da ülke ve bireysel anlamda yeni durumlar ortaya çıkarmıştır. Bu kısıtlama politikaları daha genel bir birim olarak ülkeleri ve daha özel bir birim olarak insanları ekonomik olarak çok zorlamıştır. Hava, deniz, kara ve demiryolu ile her yönden ticaret yapan ülkeler hastalık sürecinde bunu sadece belirli ve izin verilen oranda yapabilmişlerdir. Bu durum ülke ekonomisini sarsarken, doğal olarak bu sektörlerde çalışan insanları da bireysel olarak etkilemiştir. Örneğin, Çin birçok devletle ister hammadde, ister işlenmiş ürünler üzerinden ticaret yapan, geniş bir ticaret ağına sahip olan bir ülkedir. Dünyada Covid-19'un ilk çıktığ 1 ülke olarak parmakla gösterilmesi, birçok ülkenin Çin'e ve ticaretine kapılarını kapatmasıyla sonuçlanmıştır. Başka bir örnek daha verecek olursak Çin, ticarette özellikle "hizmet ticareti" olarak değerlendirebileceğimiz turizm sektöründe de hem iç hem dış turizm gelirleriyle önemli bir ekonomik gelir elde etmektedir. Bu doğrultuda pandemi ve kısıtlamaları Çin'i sadece dış turizm değil iç turizm anlamında da etkilemiştir. Pandemi sürecinde daha fazla gelişen e-ticaret ise ülke ekonomisine katkı sağlasa da tam olarak eski şekline dönüştürememiştir.

Pandemi Çin'de ticaret anlamında sarsıcı etkiler yaratırken, tam tersi çevresel anlamda olumlu ve ümit vadeden gelişmeler yaratarak bir farkındalığa sebep olmuştur. Çin'de hava kirliliği o kadar yoğundur ki pandemiden önce de Pekin (Beijing/北京), Dalian (大连) gibi bazı şehirlerde insanlar "maskeli yaşam" uygulamasını kabul etmiş durumdalardır. Örneğin 2008 Pekin Olimpiyatları'na damga vuran bir konu da "temiz hava operasyonları" olmuştur. $\mathrm{Bu}$ operasyonlar kapsamında olimpiyatlar sırasında yağmur yağmasını engellemek için gökyüzüne 21 noktadan gümüş iyodürün yanı sıra çeşitli kimyasal maddeler içeren binden fazla bomba firlatılmıştır. Bulut tohumlama olarak bilinen bu yöntemle, bulutlar etkinlik alanına ulaşmadan yağmurun erken yağması sağlanmıştır. Böylece olimpiyatlarda havası her zaman gri, pis ve bulutlu olan Pekin'de uzun zaman sonra ilk kez "mavi gökyüzü" görülmüştür. O zamanlar insan etkisiyle yapılan bu durum, pandemide kendiliğinden gerçekleşmiştir. Sokağa çıkma yasakları fabrikaların tam zamanlı çalışmasını engellemiş, böylece özellikle taşıt kullanımı azalarak hava kirlilik oranları da düşmüştür. Aynı yasaklar kentlerde gürültü kirliliklerinin de önüne geçmiş, insanların evde kalmaları ile sahiller, denizler, parklar kısacası doğa kendini yenilemek için zaman bulmuştur.

Günümüzde Çin dünyaya kendisini her ne kadar bilime, teknolojiye ve yeniliklere açık marjinal bir ülke olarak tanıtsa da özünde gelenekselci aile yapısı tarafını tam anlamıyla kaybetmemiştir. Tıpkı Türkiye'de olduğu gibi insanlar özel günlerde (Bahar Bayramı, Yeni Yıl vb.) hala büyüklerini ziyaret edip onlarla vakit geçirerek geleneksel kutlamalarını gerçekleştirirler. Bunun yanı sıra Çinliler bireyselliğe aşırı önem vermez, boş zamanlarında toplu grup etkinliklerine 
dâhil olmayı, grup gezileri yapmayı ve misafir ağırlamayı severler. Pandeminin getirmiş olduğu kısıtlamalar dünyanın her yerinde olduğu gibi Çin'de de toplu etkinlikleri olumsuz etkilemiştir. Bu durum toplumda üreten ve tüketen insan çeşitliliğini ortaya çıkarmıştır. Kısıtlamalarda eve kapanan insanlardan bazıları ailelerine daha fazla vakit ayırmayı, çekirdek aile yapısında kendilerini eğlendirip keyiflendirecek uğraşlar edinmeyi görev bilmiş ve üretken pozisyona geçmişlerdir. Bazı insanlar ise psikolojik olarak tamamen yalnızlaşmış ve tükenmiş, kapana kısılmış hissederek hiçbir üretimde bulunmadan hazıra alışarak sadece tüketici pozisyonda kalmışlardır. Bu noktada Çinliler ise bunun insan ve ülke sağlığı için geçici bir süreç olduğunu kabullenerek sabretmişlerdir.

Covid-19 bir hastalık olarak, oluşumu, semptomları, sonuçları ve çözümleri ile tıp bilimi ve alt dallarının araştırma alanıdır. Ancak bu hastalık dünyada pandemi olarak ilan edilmiştir ki bu noktada devreye diğer bilim dalları da girmektedir. Hastalık dünyayı sadece sağlık açısından değil, aynı zamanda insanların yaşam kalitesini içeren ekonomi, kültür ve çevre açısından da derinden etkilemiştir. Bu doğrultuda çalışmanın amacı Covid-19'un yaşam kalitesi adı altında insan, ekonomi ve çevre faktörlerini nasıl etkileyebildiğini gözler önüne sermektir. Virüsün dünyadaki sağlık altyapısını derin bir çıkmaza soktuğu artık bilinen bir gerçektir. Peki ya ekonomi ve çevre bundan nasıl etkilenmiştir? $\mathrm{Bu}$ çalışmanın amacı açısından saymış olduğumuz etkenler sınırlandırılarak hastalığın ilk çıktı̆̆ı ülke olarak kayıtlara geçen Çin üzerinden ele alınmıştır. Çalışmadaki sayısal verilerin güncel olabilmesi için özellikle son dönem yayınları, haberler ve Dünya Sağlık Örgütü'nün son verileri üzerinde durulmuştur. Kısacası Çin, hastalığın ilk çıktığı ülke olarak kayıtlara geçse de bugünün verileri Çin'de yaşam kalitesi adına alınan önlemlerin kayda değer olduğunu, bu mücadele sürecinde diğer ülkelere örnek olabileceğini göstermektedir.

\section{Covid-19 Nedir?}

Küresel sağlığa yönelik en son tehdit, yakın zamanda Koronavirüs Hastalığı-2019 (Covid-19) olarak adlandırılan, bir çeşit solunum yolu hastalığının devam eden salgınıdır. Covid-19 ilk olarak Aralık 2019'da tanınmıştır (WHO, 2020). Dünya Sağllk Örgütü (WHO), insandan insana bulaşma yeteneklerine sahip olduğu doğrulanan bu yeni virüsü, 11 Şubat 2020 tarihinde, resmi olarak korona virüs hastalığı-2019 (Covid-19) olarak adlandırmıştır (Chan \& Yuan ve diğ. 2020: 515). Covid-19, şiddetli akut solunum yolu yetersizliği sendromuna (SARS) neden olan virüsle yapısal olarak ilişkili yeni bir virüsün neden olduğu hızla yayılım gösteren bulaşıcı bir hastalık olarak kayıtlara geçmiştir. Korona virüsler, insanları ve aynı zamanda çok çeşitli hayvanları enfekte eden pozitif tek sarmallı büyük RNA virüsleridir. Korona virüsler ilk olarak 1966 yılında soğuk algınlığı olan hastalar üzerinde virüsleri araştıran Tyrrell ve Bynoe tarafından tanımlanmıştır (1966: 76-77). Çekirdek kabuğu ve güneşe benzetilen virüse küresel şekillerinden dolayı morfolojisi Latince'ye dayanan "taç" anlamına gelen korona virüs adı verilmiştir. Virüsün son zamanlarda alfa, beta, gama ve delta olarak dört ana alt çeşidine rastlanmıştır. Alfa ve beta-korona virüslerin görünüşte memelilerden, özellikle de yarasalardan kaynaklandığı, gama ve delta virüslerinin domuzlardan ve kuşlardan kaynaklandığı görülmüştür. Yapılan çalışmalarda virüslerin genom boyutlarının $26 \mathrm{~kb}-32 \mathrm{~kb}$ arasında değiştiği görülmüş̧ür. İnsanları enfekte edebilen yedi korona virüs alt tipi arasında beta-korona virüsler ciddi hastalık ve ölümlere neden olabiliyorken, alfa-korona virüsler asemptomatik veya hafif semptomatik enfeksiyonlara neden olmaktadır. Covid19'un, beta-korona virüslerin B soyuna ait olduğu ve SARS-CoV virüsü ile yakından ilişkili olduğu düşünülmektedir. Covid-19'un, tüm genom düzeyinde bir yarasa korona virüsü ile \%96 aynı olduğu görülmüştür (Zhou \& Yang ve diğ. 2020: 270; GISAID, 2020). Bu doğrultuda Covid-19, Çin'in Wǔhàn kentindeki Huánán (华南) deniz ürünleri pazarında hayvanlardan insanlara bulaşmıştır. Bununla birlikte hastalığın kesin bulaşma yolu konusunda hala net bir bilgi bulunmamaktadır.

Covid-19'un vaka tespitine izin veren ilk klinik belirtisi akciğer iltihaplanması olmuştur. Daha yeni raporlar, özellikle küçük çocuklar arasında gastrointestinal semptomları (sindirim sistemi) ve asemptomatik enfeksiyonları da tanımlamaktadır (Chan \& Yuan ve diğ. 2020: 520-521). Şimdiye kadar yapılan gözlemler, ortalama beş günlük bir kuluçka dönemi ( $\mathrm{Li}$, Guan \& Wu ve diğ. 2020: 1200) ve 3 günlük bir orta kuluçka süresi (0-24 gün) olduğunu göstermiştir (Guan, Ni \& Yu ve diğ. 2020: 1710). Covid-19 ile enfekte olup, enfeksiyon seyri boyunca asemptomatik kalan bireylerin oranı henüz kesin olarak değerlendirilmemiştir. Semptomatik hastalarda ise ateş, öksürük, burun tıkanıklığı, yorgunluk ve üst solunum yolu enfeksiyonlarının genellikle bir haftadan kısa bir süre sonra başladığı görülmüştür. Enfeksiyon başlangıcının bilgisayarlı tomografide görüldüğ̈̈ kadarıyla, hastaların yaklaşı \% 75 'inde akciğer iltihaplanmasına karşılık gelen nefes darlığı ve şiddetli göğüs semptomları ile birlikte ağırlaştıkları görülmüştür (Guan, Ni \& Yu ve diğ. 2020: 1708-1709). Yapılan gözlemlerde akciğer iltihaplanmasının çoğunlukla semptomatik bir enfeksiyonun ikinci veya üçüncü haftasında ortaya çıktığı da görülmüştür. 425 doğrulanmış vakanın son araştırmalarına göre, mevcut salgının her yedi günde bir etkilenen bireylerin sayısının iki katına çıkabileceği ve 
her hastanın başka bireylere enfeksiyon yaydığı gözlemlenmiştir (Chan \& Yuan ve diğ. 2020: 520-521). Yakın zamanda yapılan araştırmalar, 60 yaş ve üzeri hastaların, enfeksiyon kapma olasılığı daha düşük olan veya varsa daha hafif semptomlar ve hatta asemptomatik enfeksiyon gösterebilen çocuklara göre daha yüksek risk altında olduğunu göstermiştir (Li, Guan \& Wu ve diğ. 2020: 1204).

Covid-19'un geniş çapta yayılması, dünyanın en büyük yıllık göçünün yaşandığı Çin Bahar Bayramı döneminde meydana gelmiştir. Bu şekilde gerçekleşen kitlesel göç hareketleri, Covid-19'un yayılması için aktif bir ortam sağlamıştır; virüs, pandeminin merkez üssü Wǔhàn'dan dünyanın geri kalanına yayılmıştır. Dünya Sağlık Örgütü istatistiklerine göre, hızla yayılan Covid-19'un, 19 Haziran 2020 itibariyle 216 ülke ve bölgede 450.686 ölümle 8.385.440 kişiye bulaştığı, vaka sayısındaki büyüme eğilimine göre rapor edilmiştir. Küresel olarak, 8 Eylül 2021 itibariyle ise, WHO'ya bildirilen 4.582.338 ölüm de dâhil olmak üzere 221.648.869 onaylanmış Covid-19 vakası bulunmaktadır; 5 Eylül 2021 tarihi itibariyle ise toplam 5.352.927.296 doz aşı uygulanmıştır (WHO, 2021). Bugün enfekte kişiler hala devam etmektedir ki bu da en kötü küresel salgınlardan birinin yaşanmakta olduğunu göstermektedir.

Son 18 yılda korona virüs hastalığının ortaya çıkmasından önceki, SARS (2002 ve 2003) ve Orta Doğu solunum sendromu (MERS/ 2012) gibi iki örnekte de olduğu gibi (de Wit, van Doremalen, Falzarano \& Munster, 2016: 523), Covid-19 salgını bir yandan halk sağlığı bir yandan da ülke ekonomisi için büyük çaplı kritik zorluklar yaratmıştır. Yani bu ve benzeri salgınlar doğru yoldan insan sağlığını etkilediği gibi dolaylı olarak da küresel, sosyokültürel, ekonomik, teknolojik ve politik olmak üzere çeşitli yollardan ulusları da etkilemektedir. Bulunan aşılara rağmen, bugün hastalığın (ilk günkü kadar olmasa da) olası sosyal ve ekonomik sonuçları belirsizliğini korumaktadır. Neyse ki Covid-19 gibi dünya çaplı pandemiler ve bunlarla ilgili yapılan araştırmalar günümüzde küresel bir erişime sahiptir. $\mathrm{Bu}$ da ilerleyen süreçlerde belirsizliklerin yapılan bilgi paylaşımlarıyla aşılmasına katkı sağlayacaktır.

Salgının başlangıcında, bilim insanları ve vatandaşlar virüsün bulaşması hakkında çok az bilgiye sahip olmuşlar ve bu da kötüleşen duruma karşı etkili önlemlerin alınmasında gecikmelere neden olmuştur. 23 Ocak 2020 itibariyle Húběi eyaletinde önce Wǔhàn şehrinde, 29 Şubat 2020 itibariyle de 22 ilde 107 şehirde farklı düzeylerde sokağa çıkma yasağı politikaları yayınlanmıştır. Bu karantina politikaları, çevre de dâhil olmak üzere yaşamın her yönünü etkileyerek, Çin halk sağlığı tarihindeki en kapsamlı karantina olmuştur. Örneğin karantina politikaları insan hareketliliğini ve lojistik sektörünü sıkı bir şekilde kısıtladığından, şehirlerdeki endüstriyel faaliyetlerde ve araç kullanımında kayda değer bir düşüşe neden olmuştur (Lewis, 2020; Singh \& Chauhan, 2020: 922). Sonuç olarak da, çoğu şehir, normal koşullara kıyasla oldukça düşük düzeyde bir kirlilik yaşamıştır. Çin ile ilgili olarak ise neredeyse tüm araştırmacılar, Çin'deki farklı bölgelere odaklanarak, bu salgın sırasında hava kirliliğinin azaltılması ile insan hareketliliği kısıtlamaları arasında güçlü bir pozitif ilişki bulmuşlardır (Bao \& Zhang, 2020; Xu \& Yan ve diğg. 2020). Görülen o ki bu süreçteki iyileştirilmiş hava kalitesi ve olası sağlık yararları, Covid-19 pandemisinin olumsuz etkilerinin neden olduğu "karanlık”ttaki tek ışık olmuştur. Karantina politikalarının kirliliği ve ölümlere bağlı olarak insan psikolojisini nasıl etkilediğini kapsamlı bir şekilde anlamak önemlidir. Hem Covid-19 pandemisi hem de buna karşılık gelen önlemler, bu pandeminin ekonomik, çevresel ve sağlık etkilerinin her yönünün daha iyi anlaşılması dâhil olmak üzere her durum değerlendirilmeli ve iyileşmeyi hızlandırmaya yönelik çalışmalarla, gelecekteki salgınlar için bazı dersler çıkarılmalıdır.

\subsection{Covid-19’un Çin'de Ekonomi Üzerinde Potansiyel Etkileri}

İş dünyası küresel, demografik, politik, ekonomik, kültürel ve teknolojik durumlar başta olmak üzere çeşitli iç ve dış faktörlerden hem doğrudan hem de dolaylı olarak etkilenir. Bu etkenlerdeki değişiklikler, tüm endüstrilerde iş performanslarında da değişikliklere yol açar. Bu tür etkiler tabi ki sektöre veya bölgeye özgü olabilir. Diğer faktörler daha geniş sosyal sistemler veya insanlar tarafindan kısmen kontrol edilebilir olsa da, pandemiler aniden ortaya çıktıklarından nispeten kontrol edilemezler. Örneğin turizm, dünyanın ekonomik ve politik sistemlerinin küreselleşmiş doğası göz önüne alındığında, dış faktörlerdeki değişikliklere özellikle eğilimli bir sektördür. Turizm endüstrisi, 50'den fazla sektörle doğrudan ya da dolaylı olarak işbirliğine girer ve bu sektörlerin gelişimine değişen derecelerde katkıda bulunur; bu nedenle turizmin küresel değeri göz ardı edilemez. Pandemilerin turizm endüstrisi üzerindeki etkisi, bölge veya milliyetten bağımsız olarak da kaçınılmazdır.

Pandemiler, turizm ve dolayısıyla da ekonomi üzerinde o kadar önemli bir etkiye sahiptir ki benzer bütün süreçlerde bilim insanları tarafından bu konuda detaylı araştırmalar yapılmıştır. Örneğin Kuo, yaptığı bir araştırmada, SARS'tan etkilenen ülkelerde uluslararası turizm talebinin de olumsuz etkilendiğini, ancak kuş gribinden etkilenen ülkelerde 
bunun olmadığını tespit etmiştir (Kuo \& Chen ve diğ. 2008: 918-919). Daha sonra Page, küresel ekonomik krizin ve domuz gribinin İngiltere'deki turizm talebi üzerindeki etkilerini değerlendirmiştir (2011). Benzer şekilde Novelli, Gambiya'daki Ebola kaynaklı turizm krizini incelerken (2018), Hanrahan ve Melly de İrlanda'da küresel hastalık salgınları nedeniyle potansiyel biyogüvenlik tehditlerini önlemek için bazı önlemler alınmasını önermişlerdir (2019). Çin de Türkiye ve birçok ülke gibi Covid-19 sürecinde yaşam kalitesini etkileyen bazı kısıtlamalara gitmiştir. Okullar kapatılarak online eğitim sürecine geçilmiş, devlet kurumlarında dönüşümlü ve yarı zamanlı çalışma uygulanmış, tatil günlerinde sokağa çıkma kısıtlamaları getirilmiş ve birçok işletme hastalığın hızlı yayılımını engellemek için bu süre zarfinda kapalı tutulmuştur. Bu koşullar altında iç ve dış olarak yoğun turizm faaliyetlerinin yaşandığı Çin'de, turizm de durma noktasına gelmiştir ki bu, ülkeler için nakit döviz girdisini dolayısıyla da ekonomiyi kötü anlamda etkilemiştir.

Genel olarak bilim insanları sürdürülebilir turizm için esnekliğin gerekli olduğunu savunmuşlardır. Felaketlerden sonra turizm ve dayanıklılıkla ilgili çalışmaların, endüstrinin toparlanması için faydalı öneriler sağladığ düşünülmektedir. Bu tür araştırmaların bulgularında, afetlerden hemen sonra turist davranışlarına da odaklanılması, daha uzun vadeli davranış kalıplarının değerlendirilmesini sağlayabilmektedir.

Yeni bir pandemi olarak Covid-19 salgını Aralık 2019'da Çin'in Húběi eyaletine bağlı Wǔhàn şehrinde patlak vermiş ve insandan insana bulaşma yoluyla hızla yayılmıştır. Wǔhàn, başkent Pekin ve Guăngzhōu'yu (广州) birbirine bağlayan demiryolu hattı ile Chóngqìng (重庆) ve Shànghăi’1 (上海) birbirine bağlayan Yangtze Nehri (Chángjiāng /长 江) arasındaki kavşakta yer alan Çin'deki önemli bir ulaşım merkezidir (Zhong, Guo \& Chen, 2020: 1). Çinliler derin bir kolektivizm ile birbirlerine ve kültürlerine bağlıdırlar; bu doğrultuda Çin'de ailelerin bir araya gelmelerini simgeleyen en önemli gün "Bahar Şenlikleri" dönemidir. Bu önemli günde Çin'de sosyal yaşamın gerekliliği olarak kitlesel bir iç göç yaşanmaktadır. Ancak, Covid-19'un hızlı yayılım göstermesinden dolayı Çin hükümeti 24 Ocak 2020'de yani Bahar Şenlikleri’nden bir gün önce Wǔhàn'da karantina politikasını yürürlüğe koymuştur.

Salgınlar genel olarak ülkeleri sınırlarını kapatmaya ve havayolu hizmetlerinin işleyişini askıya almaya zorlamaktadır. Birleşmiş Milletler Dünya Turizm Örgütü (UNWTO) tarafindan bildirildiği üzere, böyle bir küresel krizin uluslararası turizm endüstrisi üzerindeki tam etkisini tahmin etmek için henüz çok erkendir; bununla birlikte, Covid-19 nihai olarak uluslararası turist oranlarında \%20 ila \%30'luk bir düşüşten sorumlu olabilir ve bu da toplam 300-450 milyar ABD Doları tutarında kayıp demektir (UNWTO, 2020). Bu kayıp 2003'teki SARS'ın etkisinden bile daha kötü olarak yorumlanmaktadır.

Çin'deki turizm patlaması, dünya çapındaki hükümetlerin ve endüstrilerin küresel dikkatini çekmiş ve turizm merkezli ülkeler, ekonomilerini desteklemek için Çinli turistlerin dikkatini çekmeye çalışmışlardır. Araştırmalara göre, Çin'in turizm pazarı sürekli gelişmektedir; hatta konuyla ilgili "yurt içi seyahat eden turist sayısının 2020 yılına kadar 2,38 milyar artarak on yıl öncesine göre \%50'den fazla artması bekleniyor" ifadeleri kullanılmıştır. Çin aynı zamanda çok sayıda bölge (örneğin Avustralya ve Yeni Zelanda) için en büyük turist pazarı olarak görülmektedir ve turist harcamaları kabaca 292 milyar ABD dolarına ulaşmıştır (Ma, 2020). Bununla birlikte, 7 Şubat 2020'de yayınlanan bir raporda ünlü ekonomistler Dass ve McDermott, turizm endüstrisinin Çin'e giden harcamalarda 22 milyar ABD doları düşüş ve Covid-19 nedeniyle 9 milyon daha az gelen turist görüleceğini tahmin etmişlerdir (2020: 6). Salgın birçok turizm merkezini etkilemiş ve potansiyel olarak 2020'de 7 ila 25 milyon daha az Çinlinin katılımıyla sonuçlanmıştır. Kısacası küresel turizm ve konaklama sektörü, hayatların kaybedildiği, işletmelerin kapanmaya zorlandığı ve halkın yüksek alarma geçtiği korkunç koşullarla karşı karşıya kalmıştır.

Korona virüs salgınının insani ve ekonomik maliyeti, sadece Çin'de değil, aynı zamanda Çin ile ticaret yapan birçok ülkede de artmıştır. Covid-19 nedeniyle sadece devlet ve özel sektör çalışanları işlerine gitmeyi bırakmamış, aynı zamanda turistler de enfeksiyon riskine maruz kalabilecekleri şüphesiyle evlerine kapanmışlardır. Sonuç olarak, önceden kalabalık toplulukların yer aldığı, camiler, kiliseler, tapınaklar, restoranlar, sinemalar, ulaşım araçları, oteller, gezi alanları, büyük marketler ve dükkânların hepsi pandemiden hızlı bir etki görmüş, bu da bu sektörlerin kapanmasına ve özellikle ticari kayıplara neden olmuştur. Her ne kadar sonuçları Covid-19 kadar ağır olmasa da aslında Çin benzer durumu 2002 yılında Serve akut solunum sendromu olarak bilinen ölümcül, akciğer iltihaplanmasına neden olan benzer bir virüsün ortaya çıkmasında da yaşamıştır. Bu sendrom sürecinde de küçük çaplı benzer kapanma süreçleri yaşanmış ve birçok küçük işletme ekonomik olarak zorluğa girerek kapanmıştır. Ne yazık ki salgın sırasında ekonomik destek sağlanamaması ya da işletmelerin nakit akışını sağlayamadıkları için borçlandırılmaları sonlarını hazırlamıştır. Covid-19 sürecinde alınan önlemlerde ise hükümet, çalışanların uzun 
tatillerde veya karantina kısıtlamaları nedeniyle işe dönememeleri durumunda tazminat ödenmesi gerektiğini belirten kurallar yayınlamıştır (Johnson \& Palmer, 2020). Bu süreçte yine önlemler kapsamında Shànghăi, Sūzhōu (苏州) ve Guăngdōng (广东) da dâhil olmak üzere birçok büyük sanayi bölgesinde, tatiller en az bir hafta daha uzatılarak işçilerin geri dönmesi engellenmiştir. Oxford'dan bazı ekonomistlere göre, Çin'in ekonomik büyümesinin geçen yılki $\% 6,1$ 'den bu yıl \%5,6’ya düşeceği tahmin edilmiştir. Bu durum, küresel ekonomik büyümeyi yıl için \%0,2 oranında azaltarak, on yıl önceki küresel mali krizden bu yana en yavaş olan yıllık \%2,3 oranına indirecektir demektir (Peter, 2020).

Çinli turistlerin diğer ülkelere yaptığı ziyaretler 2003'te 20 milyonken 2018'de 150 milyona yükselmiştir. Süreç devam ederken ise, çok sayıda havayolu şirketi Çin'e uçuşları iptal etmiştir. Dolayısıyla çok uluslu şirketlerin Çin'deki faaliyetleri de sınırlandırılmıştır. Asya turizminin de durumdan ciddi şekilde etkilenmesi ile özellikle komşu ülkeler Çinli turistlere katı seyahat yasakları uygularken, kayıpların 1,5 milyar dolar olduğu tahmin edilmektedir (Johnson \& Palmer, 2020). Çin fabrikalarındaki ekonomik düşüş ise, Tayvan ve Güney Kore'de ithal makineler ve bilgisayar çiplerinde, Şili ve Kanada'da bakırda, Almanya ve İtalya'da fabrika ekipmanlarında, Amerika ve Meksika'da otomobil sektöründe, Bangladeş ve Türkiye'de giyim fabrikalarında siparişlerin düşmesini etkilemiştir. Sonuç olarak, birkaç Asya-Pasifik ekonomisinin Çinli turist ziyaretlerindeki yavaşlamaya duyarlılığı son yirmi yılda önemli ölçüde artmıştır. Tayland, Singapur, Malezya, Vietnam, Hong Kong, Japonya, Güney Kore ve Kamboçya, Çin turizminin çöküşünün olumsuz ekonomik etkisine karşı en savunmasız Asya ekonomileri arasında yer almışlardır.

Covid-19 dünyada hızla yayılırken, birçok ülke salgını kontrol altına almak için kısa süreli kısıtlamalar uygulamıştır. Hastalığın daha fazla yayılmaması için özellikle iç ve dış seyahatlerin kısıtlanması bu tedbirlerin başında gelmiştir. Örneğin, ABD önce Çin ile seyahati durdurmuş, İngiltere ve İrlanda için de 16 Mart 2020 gece yarısında başlaması planlanan bir seyahat yasağı getirmiştir (ABC News, 2020). Bu sınır kapatmalar, halk sağlığı açısından gerekli olmakla birlikte, Covid-19'un küresel ekonomi üzerinde yarattığı gerilimi arttırmaktadır. Felaketler ve sonrasındaki turizm kısıtlamaları ile önlemler için aslında bakılabilecek en iyi örnekler, 2003 SARS salgını (Mao, 2010: 856) ve 2004 Sri Lanka'daki Arugam Körfezi'ndeki tsunamidir (Robinson, 2008: 640). Elbette ki bir felakete hazırlıklı yakalanmak her ülkenin istediği şeydir, ancak hazırlıklı olmak kadar yaşanan durumu yönetebilmek de oldukça önemlidir. Tabi ki nereden geleceği belli olmayan bu durumlara her zaman hazırlıklı olunamaz. Bu durumda ise devreye yaşananlardan ders alma, bunlar üzerine çalışmalar yaparak sonuçlarını araştırma fikri gelmektedir. Örneğin, Çinli turistlerin günlük yaşamda riskten kaçınma eğilimleri göz önüne alındığında, kriz olaylarının Çin'den giden turist akışları üzerindeki etkilerini de dikkate almak gerekmektedir (Jin, 2019: 335).

Kısacası, Covid-19'un Çin'deki ekonomiye olumsuz etkileri, kentsel yaşam kalitesini de aynı doğrultuda etkilemiştir. Çin'de bugüne kadar pek görülmemiş olan pandemik kısıtlamalar, ekonominin beklenen seviyelerin altında kalmasına neden olmuştur. Neredeyse tüm ülkelerle ticaret yapan bu ülkede alınan kapanma önlemleri, hem talep hem de arzı baskı altına almıştır. Salgın, turizmden, ticaretten, bireysel tüketici harcamalarına kadar baskı yaratırken; tatillerin uzatılması, süresiz işten çıkarmalar vb. de üretimde rötarlara neden olmuştur. Böylece turizm ve ticaretin yaşam kalitesi ve kentsel kalkınmaya önemli ekonomik gelirler sağladığı Çin'in birçok şehrinde, insanlar köylere ya da kırsal alanlara göç etmeye başlamışlardır. Özellikle Pekin, Shanghai gibi büyük şehirlerdeki işten çıkarılmalar, artan ev ve gıda fiyatları, insanları kırsal yerlere göç etmeye mecbur kılmıştır. Kırsal alanlarda artan nüfusla birlikte ise çarpık kentleşmeler, doğal kaynakların hızla tüketilmesi vb. sorunlar da görülmeye başlanmıştır. Yani şehirler nüfus bakımından rahatlarken, temiz havası, suyu, doğası ile tanımladığımız daha küçük yerleşim birimlerinde yaşam kalitesinin ve alım gücünün düşüşü gerçekleşmiştir. Ayrıca ekonomideki gerileme, sağlık sektörünü de olumsuz etkilemiştir. Daha küçük yerleşim birimlerindeki yetersiz sağlık hizmetleri, buralarda artan nüfusun sağlık ihtiyaçlarını da karşılama noktasında daha fazla yetersiz kalmıştır. Ekonomik anlamda daha güçlü sayılabilecek büyük ve ticaret merkezli şehirler bile krizi büyük kayıplarla atlatmaya çalışırken, daha küçük şehirler ve özellikle köyler ekonomik olarak derin darbeler almış; dolayısıyla bu durum alım gücü, beslenme, sağlık, eğitim gibi konularda açıklara neden olarak insanların sosyal yaşam kalitesini olumsuz olarak etkilemiştir.

\subsection{Covid-19'un Çin'de Sosyal Yaşam Üzerindeki Potansiyel Etkileri}

İnsan sosyal bir varlıktır. Bireylerin yaşam tarzları insan doğası gereği benzersizdir, fakat aynı zamanda çevredeki kültürden, geleneklerden, altyapıdan ve diğer özelliklerden alınmış, bunlarla harmanlanmıştır. Özellikle anakara Çin'de yaşayan Çinliler arasında, ulusal kültürel değerler tüketici davranışlarını büyük ölçüde etkilemektedir (Hsu \& Huang, 2016: 232). Hofstede'nin çalışmasında ele aldığı ulusal kültürel boyutlar, kolektivizmi Çin kültürünün ayırt 
edici bir özelliği olarak vurgulamaktadır (1980: 16-17). Kişisel düzeyde, Çinliler kendilerini bir grubun veya ekibin parçası olarak görme, grup içi hedeflerle ilgilenme ve grup refahı için kişisel çıkarlarını feda etmeye istekli olma eğilimindedirler (Triandis ve diğ., 1988: 331). Böyle bir kolektivist yönelim, bireysel faydalar belirsiz olduğunda bile grup işbirliğine vurgu yaparak, normlar ve yükümlülükler tarafindan büyük ölçüde yönlendirilir (Ravlin ve diğ., 2012: 775-778). Kolektivist yönelime sahip bireyler, genellikle diğerlerine benzer olma ve güçlü grup içi kayırmacılık sergileme arzusuyla motive olurlar. Ayrıca, kolektivistlerin bağlllık ölçütleri belirlenirken kişisel tutumlarından ziyade bir grup veya organizasyonun hedeflerine öncelik vermeleri beklenmektedir (Triandis, 1995). Yani Çin toplumu benmerkezci bir toplum değildir. İnsanlar genellikle topluluklarda sivrilmek değil, o topluluğun bir parçası olma ve toplum için pragmatist düşünme çabası içerisinde hareket ederler. Öyle ki Çinliler, modern dünyada bile gelenekselci aile yapılarını koruma çabasındadırlar. $\mathrm{Bu}$, onların sosyal yaşam kaliteleri kapsamında hem kendilerine hem de aileleri ve toplumlarına verdikleri önemi göstermektedir.

Bu ilkeler, Çinli bireylerin yaşam tarzı seçimlerini çerçevelemektedir. Örneğin, Çinli gezginler popüler yerleri ziyaret ederken, geleneksel olarak her şey dahil paket turları veya grup seyahatini tercih etmektedirler (Chen ve diğ., 2019: 919; Meng, 2010: 340-344). Çinliler ayrıca Bahar Şenliği gibi resmi tatillerde özellikle aileleriyle yeniden bir araya gelmek için seyahat etmekten hoşlanmaktadırlar (Wu \& Wall, 2016: 276). Bu resmi tatillerde özellikle aileleriyle bir araya gelmeleri, geleneksel aile yapısına verdikleri önemi gözler önüne sermektedir. Hatta Çinliler boş zamanlarını büyük ölçekli etkinlikler (örneğin festivaller) veya nispeten daha samimi ortamlar dâhil olmak üzere arkadaşları veya akrabalarıyla geçirmeyi tercih etmektedirler. Ayrıca ister özel günler için, ister daha rahat bir şekilde bağlantı kurmak için olsun, başkalarıyla dışarıda yemek yemekten çok hoşlanırlar. Bu durumda restoran seçimleri ve yemekleri de çok önemli bir ağ oluşturma stratejisini temsil etmektedir (Ying \& Wen, 2019: 480-481). Çinliler, yoğun müşterisi olan bir kuruluşun iyi kalitesini ve itibarını yansıttı̆̆g düşündüklerinden, özellikle yoğun restoranları tercih etmektedirler. Bunlara ek olarak, Çinliler genellikle sadece kendi yemeklerini seçmek yerine masada herkesle paylaşmak için de birkaç yemek sipariş etmektedirler (Ma, 2015: 195-196). Bu davranışları ise misafir ağırlamaya verdikleri önemin bir simgesidir ve misafirperverlik ifadesi olarak birbirlerinin tabaklarına küçük porsiyonlar eklerler. Paylaşım ve nezaket bu toplumun en belirgin özelliklerindendir. Bu duygularını özgür bir şekilde eylemsel olarak ifade edebilmeleri de onlar için hayattan memnun olmak, dolayısıyla da sosyal yaşam kalitelerini arttırmak demektir.

Pandeminin getirdiği kısıtlamalar insanların bedensel sağlıklarında ve psikolojilerinde önemli etkiler yaratmıştır. Genel anlamda bakıldığında psikolojik etkilerin, bedensel etkilerden çok daha yıkıcı ve uzun süreçli olduğu görülmektedir. Bunları ilk olarak bedensel etkiler üzerinden ele alırsak, hastalığın her bünyedeki farklı etkileriyle karşılaşırız. Örneğin bazı insanlar hastalığı ayakta atlatırken, bazı insanlar yoğun bakım ünitelerinde tedavi görmüş, hatta bazıları hayata gözlerini yummuştur. Bu noktada bedensel etkiler daha somut, gözlemlenebilirdir demek mümkündür. Daha yıkıcı olan ise psikolojik etkilerdir. Bunlar hem anlaşılması, hem de tedavi edilmesi uzun süren etkilerdir. Örneğin çoğu insanda pandemi ile ölüm ya da yakınlarının ölmesi kaygısı oluşmuştur. Bunun yanı sıra sağlık sektörüne ve dış dünyaya olan güven sarsılmaları oluşmuştur. Covid-19'un nedenleri ve süreçleriyle net olarak bilinemeyen bir hastalık olması, insanlarda büyük bir korku ve kaygı yaratmıştır. Bunun yanı sıra kısıtlamalarda uzun süre evlerinde kalan insanlarda "güvenli alan" algısının oluşmasının yanı sıra bu, zamanla asosyalleşme olarak hayattan ve insanlardan soyutlanmaya doğru ilerlemiştir. Ülkelerde kısıtlamaların esnekleşmesi ve sonrasında kaldırılması durumları ise dış çevrede ve toplum içinde, hatta iş yerlerinde insanlarda adaptasyon sıkıntısını doğurmuştur. İnsanlarda görülen bu tür huzursuzlukların tümü, yaşam kalitelerinin olumsuz etkilendiği anlamına gelmektedir.

İnsanların belli bir kesimi kısıtlama sürecinde tüketici boyutunda kalmıştır. Bu kişiler evlerinde sadece yaşamsal faaliyetlerini sürdürmüş, çoğunlukla aynı kısır döngü ile yaşamaya başlamışlardır. Bu durum bireylerde, hareketsizlik, kendini beğenmeme, bakımsızlık gibi duyguları öne çıkararak, deyim yerindeyse, insanlarda "ruhlarını doyuramama" hissiyatını yaratmıştır. Kısıtlamaların getirdiği işsizlik sorunsalı ise hem hâlihazırda işi olan, hem de iş hayatına ilk kez adım atacak bireylerde özgüven eksikliğine neden olmuştur. İş yerlerinin ve eğitim kurumlarının uzun süre kapalı olup ilerleyen süreçlerde açılması ise hem çalışanlar hem de öğrencilerde disiplinsizlik sorunlarını ortaya çıkarmıştır. Kısıtlama sürecindeki insanların bir diğerlerini ise üretici boyuttakiler oluşturmaktadır. Bunlar pandemi sürecinde ruhsal sağlıklarını ayakta tutmayı başarabilmiş insanlardır. Üretici kesimdeki insanlar kısıtlama sürecinden hem maddi hem de manevi yönden kendilerini doyurabilmişlerdir. Bu kesime örnek olarak belli hobiler edinenler, evde e-ticarete başlayanlar hatta kitap okumaya başlayanlar bile örnek gösterilebilmektedir. 
Çin, online yaşama çoğu ülkeden önce geçip, uyum sağlamıştır. Sosyal ilişkilere ne kadar önem verildiğinden bahsettiğimiz bu ülkede somut sosyalliğin ${ }^{3}$ dışında, soyut sosyallik ${ }^{4}$ de oldukça ön plandadır. İnternet Çinliler için su kadar hayati önem taşımaktadır. Hatta bu boyut son birkaç yıldır o kadar abartılmıştır ki turistlere bile hissettirilmeden dayatılmaktadır. Örneğin, Çinlilerin çoğu nakit para ve banka kartını neredeyse tamamen bırakmıșlardır. Bu ülkede alışveriş genellikle telefonlara indirilen uygulamalar ile online hesaplar üzerinden yapılmaktadır. Online yaşam ülkede öyle bir yer edinmiştir ki, Çin bankalarında hesapları olmayan ve uygulamalardan faydalanamayan turistler için bu durum ciddi sıkıntılara neden olmaktadır. Ülkede internete olan bu düşkünlük, Pandemi kısıtlamaları sürecinde daha da fazla artmıştır. $\mathrm{Bu}$ artış her ne kadar e-ticareti hareketlendirse de insanlarda farklı etkileri ortaya çıkarmıştır. Örneğin, somut olarak sosyalleşme durma noktasına gelindiğinde, insanlar sosyal medya üzerinden sosyalleşmeye başlamışlardır. Bu durum kişiler arasındaki sosyal ve ekonomik durumlarda belirsizlik yaratmış, özenme güdüsünde olan insanlarda ve ilişkilerinde "sahte" bir yaşamı ortaya çıkarmıştır. Böylece insanlarda güven problemi oluşmaya başlamıştır.

Çin'in genel nüfusu ve sosyal kaynakları, bireylerin yaşam tarzlarını da etkilemektedir. Dünyanın en kalabalık ülkesi olan Çin, 10 Eylül 2021 itibariyle 1,5 milyar nüfusa ev sahipliği yapıyordur (Worldometer, 2020a) ki bu dünya nüfusunun \%18,47'si demektir. Çin'in tahmini nüfus yoğunluğu $\mathrm{km}^{2}$ başına $145 \mathrm{kişidir} \mathrm{ve} \mathrm{bu,} \mathrm{örneğin} \mathrm{km}^{2}$ başına 3,3 kişinin düş̧üğü Avustralya (Australian Bureau of Statistics, 2018) gibi ülkelerden kat ve kat daha fazladır. Çin vatandaşları bu nedenle kalabalık toplu taşıma araçlarına da alışmışıిı. Çin'de turistik yerler, parklar ve bahçeler gibi halka açık alanlar, özellikle resmi tatillerde genellikle insanlarla doludur. Çinliler, bu alanlarda toplu yürüyüş, spor ve dans gösterileri yapmaktan, yani sosyalleşmekten keyif alırlar. Ancak, bu kalabalıklaşma eğilimi, Covid-19 salgını sırasında hastalığın insandan insana çabuk bulaşma özelliğinden dolayı büyük bir endişe yaratmıştır.

İtalya, İngiltere, Avusturya, Fransa, Portekiz ve Türkiye gibi diğer ülkelerde de benzer şekilde virüsün yayılmasını azaltmak amacıyla alınan tedbirler gibi Çin Hükümeti de kişisel teması azaltmak ve fiziksel mesafeyi artırmak için önlemler almıştır. Bu sosyal mesafe politikalarının bir parçası olarak yetkililer, insanları toplu ortamlardan kaçınmaya teşvik etmişlerdir. Bu doğrultuda büyük kamu etkinlikleri ertelenmiş veya iptal edilmiş, yoğun nüfuslu yerler (örneğin okullar, üniversiteler, devlet daireleri, kütüphaneler, müzeler ve fabrikalar) salgının zirvesinde geçici olarak kapatılmıştır (The State Council of the People's Republic of China, 2020). Covid-19 zirvedeyken, kentsel toplu taşıma sistemlerinin sınırlı bölümleri çalıştırılmış ve tüm iller arası otobüs güzergâhları hizmet dışı bırakılmıştır. Çin vatandaşları da eve yakın kalarak, sosyal teması sınırlayarak ve dışarı çıkarken koruyucu maske takarak kendilerini Covid-19'a karşı korumak zorunda kalmışlardır. Çin Hükümeti, hastalık kontrolünü ve önlenmesini daha da teşvik etmek için katı seyahat kısıtlamaları getirmiş ve potansiyel olarak enfekte olmuş kişileri kendi kendini karantinaya almaya teşvik etmiştir (Cowling \& Lim, 2020).

Worldometer'a göre, 1 Nisan 2020 itibariyle yeni vaka bildirilmeyen Çin'de, Covid-19 vakalarının sayısı önemli ölçüde azalmıştır (2020b). 9 Eylül 2021 itibariyle ise sadece 47 yeni vaka tespit edilmiştir (National Health Commission of the Peoples's Republic of China, 2021). Pandemi sürecindeki politikalar, yüzyıllarca yıl süren tarihi değerlerine sahip çıkan Çin vatandaşlarının yaşam tarzlarını geçici olarak değiştirmiştir. Bu pandeminin yakın zamanda ortaya çıkmış olması göz önüne alındığında, Çin vatandaşlarının Covid-19'a davranışsal tepkilerini araştırarak, afet sonrası etkili toparlanma adına planlar tasarlamak için daha fazla araştırmaya ihtiyaç vardır. Ancak, bugünkü görünüşe bakılırsa Çin Hükümeti’nin virüsü kontrol altına alma çabaları etkilidir demek mümkündür.

Covid-19'un Çin'deki sosyal yaşama etkileri, kentsel yaşam kalitesini olumlu ve olumsuz anlamda iki yönlü olarak etkilemiştir. Normal zamanlarında oldukça sosyal yaşayan Çin halkı, pandemi kısıtlamalarıyla gelen kapanma süreçlerine maruz kalmışlardır. Alışkın olmadıkları bu durum bireylerin içlerine kapanmalarına, sosyal medya bağımlılığına ve sanal arkadaşlıkların artmasına yol açarak, sosyal yaşam kalitesini olumsuz anlamda etkilemiştir. İşe ve okula gidemeyen bireylerin bir kısmı kendilerini sadece dört duvar arasında yaşarken bulmuş, bu durumu kabullenememek onlarda psikolojik sorunlara neden olmuştur ki bu da direkt olarak sosyal yaşam kalitelerinin düştüğü gerçeğini göstermektedir. Diğer yandan, üretici konumuna geçen, hayatın ve yaşamanın değerini anlayan bireyler kendi psikolojilerini toparlamaya ve sosyal yaşam kalitelerini arttırmaya odaklanmışlardır. Hayata karşı daha duyarlı hale gelen bu insanlar, gereksiz tüketimden kaçınıp daha bilinçli ve düşünceli davranışlarla kentlerin yaşam kalitesinin artmasına da katkıda bulunmuşlardır.

\footnotetext{
${ }^{3}$ İnsanlarla yüz yüze görüşme, toplanma vb. "somut sosyallik" olarak nitelendirilmiştir.

${ }^{4}$ Bireylerin internet üzerinden sosyal medya uygulamaları, mesajlaşma vb. aktiviteleri "soyut sosyallik" olarak nitelendirilmiştir.
} 


\subsection{Covid-19'un Çin'de Çevre Üzerindeki Potansiyel Etkileri}

Dünya Sağlık Örgütü'nün (WHO) yaptığı araştırmalara göre hava kalitesi insan sağlığı için çok önemlidir; ancak dünya nüfusunun \%91'i kötü hava kalitesinin izin verilen sınırları aştığı yerlerde yaşamaktadır (WHO, 2016). Küresel ölümlerin nedenlerinin önemli bir yüzdelik diliminde de hava kalitesinin bozulması (yani hava kirliliği) kendini göstermektedir (Zhang ve diğ. 2017: 705). Bu bağlamda, 2016 WHO raporunda hava kirliliğinin dünyadaki toplam ölümlerin yaklaşık \%8'ine katkıda bulunduğu; kirlilikten en çok etkilenen ülkelerin Afrika, Asya ve Avrupa'nın bir bölümünde bulunanlar olduğu belirtilmiştir (WHO, 2016).

Birçok ülkede olduğu gibi Çin de Covid-19'un yayılmasını kontrol altına alabilmek için katı trafik kısıtlamalarının yanı sıra farklı karantina önlemleri uygulamıştır. Bu önlemler görünürde insanlar için alınmış olsa da hava kirliliğinde de değişiklikler yaratmıştır. Karantina uygulamasıyla Nitrojen Dioksit $\left(\mathrm{NO}_{2}\right)$, Wǔhàn ve Çin'de sırasıyla $22,8 \mu \mathrm{g} / \mathrm{m}^{3}$ ve $12,9 \mu \mathrm{g} / \mathrm{m}^{3}$ azaltılmıştır. Partiküler madde (PM 2.5) Wǔhàn'da $1,4 \mu \mathrm{g} / \mathrm{m}^{3}$ düşerken, 367 şehirde $18,9 \mu \mathrm{g} / \mathrm{m}^{3}$ düşüş göstermiştir. Benzer şekilde, Avrupa'da katı karantina önlemleri uygulayan ilk şehirler olan Madrid, Roma ve Paris'te Nitrojen Dioksit $\left(\mathrm{NO}_{2}\right)$ konsantrasyonlarında, Copernicus Sentinel-5P uydusundan alınan verilere göre, önemli bir düşüş olduğu gözlemlenmiştir (Zambrano-Monserrate ve diğ. 2020: 2). Ayrıca, Avrupa Birliği'nin Copernicus Atmosfer İzleme Servisi (CAMS), geçtiğimiz Şubat ayında önceki üç yıla göre PM 2.5 'te bir düşüş gözlemlemiştir. CAMS'a göre, Şubat 2020 için aylık ortalama ile Şubat 2017, 2018 ve 2019 için aylık ortalamalar arasındaki fark karşılaştırıldığında, Çin'in büyük bölgelerinde PM 2.5'te yaklaşık \%20-30'luk bir düşüş gözlemlenmiştir (2020). Çin için görülen o ki, bu zamana kadar yapılan hava kalitesi iyileştirme çabalarında, ölümlere sebep olan Covid-19 pandemisinin de olumlu olarak etkisi olmuştur.

Havanın yanı sıra sahiller de ülkelerin en önemli doğal sermaye ve kentsel yaşam varlıklarındandır (ZambranoMonserrate ve diğ. 2018: 200-202). Sahiller, kıyı topluluklarının hayatta kalması için kritik olan ve aşırı sömürüden korunması gereken içsel değerlere sahip hizmetler (arazi, rekreasyon, kum ve turizm) sağlarlar (Lucrezi ve diğ. 2016: 10-13). Ancak insanlar tarafından sorumsuzca kullanım, dünyada birçok sahil ve plajın kirlilik sorunu yaşamasına neden olmuştur. Yeni koranavirüs pandemisi nedeniyle alınan sosyal mesafe önlemlerinin bir sonucu olarak turist azlı̆̆ı, dünyadaki birçok sahilin görünümünde tıpkı hava gibi kayda değer bir değiş̧ikliğe neden olmuştur. Örneğin, Meksika (Acapulco), Ekvador (Salinas) ve İspanya (Barselona) gibi ülkelerin sahilleri artık daha temiz ve berrak sulara sahip görünmektedir.

Pandeminin bir diğer önemli etkisi ise yine kentsel yaşam kalitesini etkileyen çevresel gürültü kirliliğidir. Çevresel gürültü, antropojenik (endüstriyel veya ticari) faaliyetler, motorlu taşıtların geçişi ve yüksek ses seviyelerine sahip her şey tarafından üretilebilecek istenmeyen sesler olarak tanımlanmaktadır. Bu çevresel gürültü aslında, insan ve çevre için sağlık sorunlarına neden olabilen ve ekosistemlerin doğasını değiştiren ana rahatsızlık kaynaklarından biridir (Zambrano-Monserrate \& Ruano, 2019: 1-3). Çoğu hükümet tarafından karantina önlemlerinin dayatılması, insanların evde kalmasına neden olmuştur. Bununla birlikte, özel ve toplu taşıma kullanımı önemli ölçüde azalmıştır. Ayrıca ticari faaliyetler neredeyse tamamen durmuştur. Tüm bu değişiklikler, dünyadaki çoğu şehirde gürültü seviyesinin önemli ölçüde düşmesine ve yaşam kalitesinin artmasına neden olmuştur.

Dünyadaki ormansızlaşma, erozyon, su ve hava kirliliği gibi çeşitli çevresel sorunlar, organik ve inorganik atık üretimine dolaylı olarak etki etmektedir (Mourad, 2016: 461-462). Birçok ülkede uygulanan karantina politikaları, insanların online alışveriş taleplerinde artışa neden olmuştur. Bu durum sonucunda ise bir yandan insanların ürettiği organik atık miktarında, diğer yandan da paketli gelen yiyeceklerden kaynaklı inorganik atık miktarında artış olmuştur. Hastalık tam olarak kontrol altına alınamadığı için tabi ki tıbbi atık miktarında da artış olmuştur. Örneğin, Wǔhàn'daki hastaneler önceden yaklaşık olarak 50 tondan az tıbbi atık üretirken, pandemi sürecinde bu oran günde ortalama 240 ton olarak ölçülmüsstür (Calma, 2020). Bunun yanı sıra salgın sürecinde her ülkedeki eldiven ve maske kullanım miktarı artmış, doğal olarak bunların çoğu atık olarak doğaya yayılmıştır.

Atıkların geri dönüştürülerek doğaya ve hayata yeniden kazandırılması aslında sadece bugün değil yıllardır bütün ülkeleri yakından ilgilendiren ve kentsel yaşam kalitesini de etkileyen çevresel bir problem olmuştur. Çünkü geri dönüşüm, başta doğal kaynakları ve doğayı korumanın yanı sıra enerji tasarrufu sağlayarak kirliliği önlemenin de etkin bir yoludur (Varotto \& Spagnolli, 2017: 180). Ne yazık ki pandeminin bir sonucu olarak, hastalığın bu geri dönüşüm merkezlerinde yayılma riskinden dolayı, bazı ülkeler geri dönüşüm programlarını geçici süreyle durdurmuş̧lardır. Yine aynı şekilde hastalığın yayılma riski çoğu ülkede tek kullanımlık poşet yasaklarının da kaldırılmasını beraberinde getirmiştir ki bu da bir diğer atık ve israf sorunudur. 
Çin'de pandemi sürecinde temizliğin öneminin anlaşılması ile bir yandan su tüketimi artarken, diğer yandan hastalığın atık su yoluyla bulaşmasını engellemek için su arıtma tesisleri dezenfeksiyon rutinlerinde daha fazla güçlendirmelere zorlanmıştır. Bu yöntem aslında beraberinde başka sorunları da getirmiştir. Çünkü virüsün suda hayatta kalma olasılığına dair net bir kanıt yoktur (WHO, 2020b), ancak arıtım tesislerine baskı yapılması daha fazla klor kullanılmasına sebep olmuştur ki bu da insan sağlığı için oldukça zararlıdır.

Kısacası, çalışmada örneklendirilen bütün çevresel sorunlar ve çözümleri, kentsel yaşam kalitesini içermektedir. Bu problemlere çözümler bulunması demek insanların daha sağlıklı ve mutlu bir dünyada yaşayabilmeleri, yani memnun olmaları demektir ki bu da yaşam kalitesinin artmasını ifade etmektedir. Pandemi sürecindeki kısıtlamalarla kapalı kalan fabrikalar, trafiğe çıkamayan araçlar hava kalitesini olumlu anlamda etkilemiştir. Havanın, denizlerin temizlenmesi, bilinçli tüketim, atıkların kontrollü yok edilmesi, gürültü kirliliğinin azaltılması, yeşil alanların arttırılması gibi girişimler, pandeminin kentsel yaşam kalitesine olumlu etkilerini göstermektedir. Tüm bu girişimler daha kaliteli yaşam alanlarının oluşturulması ve hem şuanda yaşayan insanlara hem de gelecek nesillere şans verilebilmesi açısından oldukça önemli adımlardır.

\section{SONUÇ:}

Arthur Schopenhauer gerçeklerle ilgili olarak: "Tüm gerçekler üç aşamadan geçer: İlk aşamada alay konusu olurlar. İkinci aşamada şiddetle karşı çıkmalara maruz kalırlar. Üçüncü aşamada ise apaçık kabul edilirler.” şeklinde açıklamada bulunmuştur. Bu bakış açısından yola çıkarak Çin'de Covid-19'un evrimini incelediğimizde, aslında benzer sonuçlara ulaşmaktayız. İlk aşama için yapılan açıklamalara bakıldığında Çin'in hastalığı dünyaya çok geç bildirdiği belirtilmektedir. Öyle ki bu durum bizi Schopenhauer'un "alay konusu"na getirmektedir. Çünkü Çin, belki ekonomik ve siyasi çıkarları doğrultusunda ve belki de hastalığı kendi başlarına çözebilecekleri inancıyla başlarda bunu gelip geçici basit bir hastalık olarak değerlendirmiştir. Aynı şekilde insanlara bakıldığında kısıtlamalara uymama, aşı olmayı reddetme, maske takmama, karantinada kalmayı reddetme gibi davranışları da bu ilk alay aşaması olarak değerlendirebiliriz. Daha sonraki süreçlerde hastalığın aslında ilk Çin'de çıkmadığı, bildirimin Dünya Sağlık Örgütü'ne hemen yapıldığı şeklinde açıklamalarla Çin Schopenhauer'un ikinci gerçek aşamasını yaşamıştır. Bizlerin sosyal medya aracılığıyla takip ettiği Çin'de ikinci aşama insanlar üzerinde kelimenin tam anlamıyla "şiddetli" olmuştur. Özellikle karantina sürecinde kalmaktan çekinen insanlar hastanelere Çin kolluk kuvvetlerinin yardımıyla zorla götürülmüşlerdir. İnsan psikolojisi bu aşamada bilmedikleri bu hastalığa karşı direnç göstererek onu kabul etmeme algısı oluşturmuştur. Schopenhauer'un üçüncü aşaması ise bugün Çin dâhil tüm dünyada hissedilmektedir. Çin de diğer ülkeler de birbirlerini suçlamayı bırakmış, hastalığın ortaya çıkışı, neden ve nasıl bulaştığı gibi konularda bilimsel çalışmalarını paylaşmaya, bu şekilde de aşı üretmeye başlamışlardır. Aynı şekilde insanların bu üçüncü gerçeklik aşaması ise sadece aşı olmalarıyla bile açıklanabilmektedir.

Covid-19 çok yakın geçmişte ortaya çıkmış bir hastalık olsa da hastalığın hızlı yayılımı, ölümcül etkisi, aşının tam olarak bulunamamış olması ve her geçen gün ortaya çıkan mutasyonlu yeni varyantlarıyla sadece Çin'in değil tüm dünyanın gündemine oturmuştur. Konuyla ilgilenen bilim merkezlerinin dışında, evlerde bile herkes hastalıkla ilgili yeni gelişmeleri merakla takip etmektedir.

Tam olarak nasıl ortaya çıktığı bile netleştirilemeyen bu hastalık tüm dünyayı çaresiz bırakmıştır. Hastalık, teknoloji ve bilim ne kadar ilerlerse ilerlesin, sağlık sektöründeki hala devam eden eksiklikleri gün yüzüne çıkarmıştır. Covid19'un ilk ortaya çıktığı ülke olarak gösterilen Çin, bugün aynı zamanda hastalığın olası etkilerini hafifleten ilk aşıyı da bulan ülkedir. Buna rağmen Çin de diğer ülkeler gibi Covid-19'un her alanda potansiyel etkilerini yaşamıştır.

Çin, son yıllarda ekonomik açıdan büyüyen ülkeler arasında boy göstermeye başlamışken, bu hastalık ülkenin ekonomisini olumsuz yönde etkilemiştir. Covid-19 ile gelen yasaklar ve sınır kapatmalar, büyük bir ticaret ağına sahip olan ülkeyi geçici süreliğine kendi sessizliğine bırakmıştır. Ekonomide bir günlük bir kayıp ülke bazında milyon dolarlara mal olmaktadır. Çin, Covid-19'un en büyük etkisini ticaret ve turizmden yana almıştır. Sınırlamalara mecbur kalan her ülkede olduğu gibi Çin'de hastalığın bulaşıcı etkisi nedeniyle sadece ticaret değil, iç ve dış turizm de sekteye uğramıştır.

Covid-19 Çin'i ekonomik anlamda yıpratsa bile çevre anlamında olumlu etkileri de olmuştur. Çin yıllardır hava kirliliğine maruz kalan ülkelerden biridir. Bu kirliliğin trafik, endüstriyel atıklar, kömür kullanımı gibi pek çok nedeni vardır. Bu durumda Çin'in bazı kentlerinde insanlar yıllardır bizim sadece pandemi sürecinde tanıştığımız "maskeli hayatı" yaşamaktadırlar. Ülke hava kirliliği konusunda sürekli gündeme geldiği kadar, bu sorunla baş edebilmek için 
attığı adımlarla da gündeme gelmiştir. Örneğin, kirliliği azaltmak için araç kullanımları kısıtlanmış, kömür yerine yenilebilir enerji üretimi projelerine 360 milyar dolar harcanarak güneş ve rüzgâr enerjisi kullanımı oluşturulmaya çalışılmıştır. Çin'in uzun zamandır ciddiye aldığı ve yatırımlar yaptığı "çevre kirliliği”, pandemi sürecinde kendiliğinden gerçekleşmiştir. Kısıtlamalarla insanların sokağa çıkamaması, sanayi ve fabrikaların durma boyutuna gelmesi, trafiğin azalması hem gürültü hem de hava kirliliğini azaltmıştır. Kirlilikten sürekli sisli görünen havada mavi gökyüzünün görülmesi, denizlerde, sahillerde, park ve bahçelerde doğanın yenilenmesiyle daha temiz bir görüntünün oluşması, pandeminin ülkedeki çevre sorunlarına ve yaşam kalitesine olumlu etkilerini göstererek adeta bir "umut" olmuştur.

Covid-19 ve kısıtlamaları, geleneklerine bağlı ve sosyal yaşamayı seven Çinlileri de etkilemiştir. Hastalığın ölümcül etkileri bazı insanlarda yaşama arzusunu güçlendirirken, bazı insanları da bunalıma sokmuştur. Geleneklerine bağlı, atalarına değer veren Çinliler bu süreçte bireysellikten ziyade toplumsal düşünerek önlemlere saygı göstermiş ve sürecin kontrollü ilerlemesine yardımcı olmuşlardır. Pandemide aile kavramı ve buna verilen değerler öne çıkmıştır. Öte yandan sokağa çıkma kısıtlamaları ve işsizlik normal hayatında çok sosyal yaşayan insanları sessizliğe iterek psikolojik olarak bireysel bunalım ve buhranlara sebep olmuştur.

Kısacası her ülke Covid-19 pandemisinden ve kısıtlamalarından "yaşam kalitesi” bağlamında olumlu-olumsuz olarak etkilenmiştir. Çalışmada kentsel yaşam kalitesi kapsamında özellikle ele alınan ekonomik, sosyal yaşam ve çevre konularında bu etkilerin yoğunluğu gösterilmeye çalışılmıştır. Çin gibi kalabalık nüfusa sahip olan ülkelerde bu etkiler daha yoğun yaşanmaktadır. Hala devam eden hastalı̆̆ın ileri vadedeki etkileri ise henüz net olarak tahmin edilememektedir. Ancak, alınan önlemlere bakıldığında nüfusuna ve ilk dönem kayıplarına rağmen Çin şuan hastalık konusunda pek çok ülkeden daha iyi, normal hayata yeniden dönmüş ve yaşam kalitesini de hastalık öncesi sürecine yeniden getirebilmiş durumdadır. Bu da demek oluyor ki, Çin hastalıkla savaşma sürecinde birçok ülkenin örnek almas1 gereken yollar izlemektedir.

\section{Etik Standart ile Uyumluluk}

Çıkar Çatışması: Yazarlar herhangi bir çıkar çatışmasının olmadığını beyan eder.

Etik Kurul İzni: Bu çalışma için etik kurul iznine gerek yoktur.

Finansal Destek: Bulunmamaktadır.

\section{KAYNAKÇA:}

ABC News. (2020, Mart 14). Coronavirus update: Morrison brings in travel restrictions, Australian cases pass 250, Donald Trump's COVID-19 test is clear. https://www.abc.net.au/news/2020-03-15/coronavirus-updatelatest-news-us-travel-ban-extended-trump-test/12057094 Erişim tarihi: 10.09.2021.

Australian Bureau of $\quad$ Statistics. (2018, Nisan 24). Population density. https://www.abs.gov.au/AUSSTATS/abs@.nsf/Previousproducts/3218.0Main\%20Features70201617 ? opendocument $\&$ tabname $=$ Summary $\&$ prodno $=3218.0 \&$ issue $=2016-17 \&$ num $=\& v i e w=~$ Erişim $\quad$ Tarihi: 10.09 .2021

Bao, R. \& Zhang, A. (2020). "Does lockdown reduce air pollution? evidence from 44 cities in northern China." Science of the Total Environment. 731, 139052. https://doi.org/10.1016/j.scitotenv.2020.139052

Calma, J. (2020, Mart 26). The Covid-19 pandemic is generating tons of medical waste. The Verge. https://www.theverge.com/2020/3/26/21194647/the-covid-19-pandemic-is-generating-tons-of-medical-waste Erişim Tarihi: 11.09 .2021

Chan, J. W. , Yuan, S., Kok, K.H. \& Chu, H. (Ed.). (2020). “A familial cluster of pneumonia associated with the 2019 novel coronavirus indicating person-to-person transmission: a study of a family cluster." The Lancet. 395, 514-523. https://doi.org/10.1016/S0140-6736(20)30154-9 
Chen, N., Masiero, L. \& Hsu, C. (2019). "Chinese outbound tourist preferences for all-inclusive group package tours: a latent class choice model." Journal of Travel Research. 58(6), 916-931. https://doi.org/10.1177/0047287518794331

Copernicus Europe's Eyas on Earth (CAMS). (2020, Mart 4). Amid Coronavirus outbreak: Copernicus monitors reduction of particulate matter (PM2.5) over China. https://www.copernicus.eu/en/amid-coronavirusoutbreak-copernicus-monitors-reduction-particulate-matter-pm25-over-china Erişim Tarihi: 08.09.2021

Cowling, B. \& Lim, W. (2020, Mart 13). They’ve contained the coronavirus: here's how. The New York Times. https://www.nytimes.com/2020/03/13/opinion/coronavirus-best-response.html Erişim Tarihi: 02.09.2021

Dass, M. \& McDermott, H. (2020). “Travel \& Tourism: Global Potential Impact of the Coronavirus." Tourism Economics: An Oxford Economics Company. 1-10. https://s3.amazonaws.com/tourismeconomics/craft/Latest-Research-Docs/Potential-Impact-of-the-Coronavirus.pdf Erişim Tarihi: 09.09.2021.

De Wit, E., van Doremalen, N., Falzarano, D. \& Munster, V. J. (2016). "SARS and MERS: recent insights into emerging coranaviruses." Nature Reviews Microbiology. 14(8), 523-534. https://www.nature.com/articles/nrmicro.2016.81 Erişim Tarihi: 09.09.2021.

Global Initiative on Sharing All Influenza Data (GISAID). (2020, Haziran 4). Phylogeny of SARS-like betacoronaviruses including novel coronavirus (nCoV). https://nextstrain.org/groups/blab/sars-like-cov Erişim tarihi: 09.09.2021.

Görün, M. \& Kara, M. (2010). “Kentsel Dönüşüm ve Sosyal Girişimcilik Bağlamında Türkiye'de Kentsel Yaşam Kalitesinin Artırılması.” Yönetim Bilimleri Dergisi. $137-164$. https://dergipark.org.tr/tr/download/article-file/704543 Erişim Tarihi: 08.10.2021.

Guan, W., Ni, Z. \& Yu, H. ve diğ. (2020). “2019 冠状病毒病中国患者的临床特征(Clinical characteristics of 2019 novel coronavirus infection in China)." The New England Journal of Medicine. 382(18), 1708-1720. https://www.nejm.org/doi/10.1056/NEJMoa2002032

Hanrahan, J.D. \& Melly, D. (2019). "Tourist biosecurity awareness and risk mitigation for outdoor recreation: Management implications for Ireland." European Journal of TourismResearch. 22, 45-61. https://doi.org/10.1016/j.jort.2020.100313

Hofstede, G. (1980). “Culture and organizations." International Studies of Management \& Organization. 10(4), 1541. https://doi.org/10.1080/00208825.1980.11656300

Hsu, C. \& Huang, S. (2016). "Reconfiguring Chinese cultural values and their tourism implications." Tourism Management. 54, 230-242. https://doi.org/10.1016/j.tourman.2015.11.011

Jin, X. Qu, M. \& Bao, J. (2019). "Impact of crisis events on Chinese outbound tourist flow: a framework for postevents growth." Tourism Management. 74, 334-344. https://doi.org/10.1016/j.tourman.2019.04.011

Johnson, K. \& Palmer, J. (2020, Şubat 28). Knock-on Effects of China's Coronavirus May Be Worse Than Thought. Foreign Policy. https://foreignpolicy.com/2020/02/03/knock-on-effects-china-coronavirus-weak-economymarkets/ Erişim Tarihi: 09.09.2021.

Kuo, H.-I., Chen, C.-C., Tseng, W.-C., Ju, L.-F. \& Huang, B.-W. (2008). “Assessing impacts of SARS and avian flu on international tourism demand to Asia." Tourism Management. 29(5), 917-928. https://doi.org/10.1016/j.tourman.2007.10.006

Lewis, S. (2020, Nisan 22). Before-and-after photos show dramatic decline in air pollution around the world during coronavirus lockdown. CBS News. https://www.cbsnews.com/news/coronavirus-photos-decline-air-pollutionlockdown/ Erişim tarihi: 09.09.2021. 
Li, Q., Guan, X. \& Wu, P. ve di g. (2020). “新型冠状病毒感染肺炎在中国武汉的初期传播动力学(Early transmission dynamics in Wuhan, China, of novel coronavirus-infected pneumonia.)" The New England Journal of Medicine. 382(13), 1199- 1207. https://doi.org/10.1056/NEJMoa2001316

Lucrezi, S., Saayman,M. \& Van der Merwe, P. (2016). "An assessment tool for sandy beaches: a case study for integrating beach description, human dimension, and economic factors to identify priority management issues." Ocean \& Coastal Management 121, 1-22. https://doi.org/10.1016/j.ocecoaman.2015.12.003

Ma, G. (2015). "Food, eating behavior, and culture in chinese society." Journal of Ethnic Foods. 2(4), 195-199. https://doi.org/10.1016/j.jef.2015.11.004

Ma, Y. (2020, Kasım 17), Tourism industry in China - Statistics \& facts. Statista. https://www.statista.com/topics/1210/tourism-industry-in-china/ Erişim Tarihi: 09.09.2021

Mao, C., Ding, C. \& Lee, H. (2010). "Post-SARS tourist arrival recovery patterns: an analysis based on a catastrophe theory.” Tourism Management. 31(6), 855-861. https://doi.org/10.1016/j.tourman.2009.09.003

Marans, R. (2007). "Kentsel yaşam kalitesi." Handan Dülger Türkoğlu (çev.). Mimarlık Dergisi. 335. http://www.mimarlikdergisi.com/index.cfm?sayfa=mimarlik\&DergiSayi=53\&RecID=1326

Marshall, S. \& Banister, D. (2007). Land Use and Transport. Elsevier Ltd. Amsterdam: London.

Meng, F. (2010). "Individualism/collectivism and group travel behavior: a cross-cultural perspective." International Journal of Culture. Tourism and Hospitality Research. 4(4), 340-351. https://doi.org/10.1108/17506181011081514

Mourad, M. (2016). "Recycling, recovering and preventing "food waste": competing solutions for food systems sustainability in the United States and France." Journal of Cleaner Production. 126, 461-477. https://doi.org/10.1016/j.jclepro.2016.03.084

National Health Commission of the Peoples's Republic of China. (2021, Eylül 10). 截至9月9日24 时新型冠状病 毒肺炎疫情最新情况 (9 Eylül Itibariyle Yeni tip Korana virüs Salgınının Son Durum Raporu) http://www.nhc.gov.cn/xcs/yqtb/202109/0cad54ae53804c7192daf85cb1bd08a1.shtml Erişim Tarihi: 10.09 .2021

Novelli, M., Burgess, L.G., Jones, A. \& Ritchie, B.W. (2018). "No Ebola . . . still doomed' - the Ebolainduced tourism crisis." Annals of Tourism Research. 70, 76-87. https://doi.org/10.1016/j.annals.2018.03.006

Page, S., Song, H. \& Wu, D.C. (2011). "Assessing the impacts of the global economic crisis and swine flu on inbound tourism demand in the United Kingdom." Journal of Travel Research. 51(2), 142-153. https://doi.org/10.1177/0047287511400754

Peter, S. (2020, Şubat 26). China's Coronavirus Has Revived Global Economic Fears.The New York Times. https://www.nytimes.com/2020/01/27/business/coronavirus-china-economic-impact.html Erişim tarihi: 04.12.2021.

Ravlin, E., Liao, Y., Morrell, D., Au, K. \& Thomas, D. (2012). "Collectivist orientation and the psychological contract: mediating effects of creditor exchange ideology." Journal of International Business Studies. 43(8), 772-782. https://www.jstor.org/stable/41674521?seq=1\#metadata_info_tab_contents

Robinson, L. \& Jarvie, J. (2008). "Post-disaster community tourism recovery: the tsunami and arugam Bay, Sri Lanka." Disasters. 32(4), 631-645. https://doi.org/10.1111/j.1467-7717.2008.01058.x

Singh, R. P. \& Chauhan, A. (2020). "Impact of lockdown on air quality in India during COVID-19 pandemic." Air Quality Atmosphere \& Health. 13, 921-928. https://doi.org/10.1007/s11869-020-00863-1 
The Free Dictionary. (2012). https://www.thefreedictionary.com/quality+of+life Erişim Tarihi: 08.12.2021.

The State Council of the People's Republic of China. (2020, Şubat 3). The state council's announcement on the arrangement of public holidays in 2020. http://www.gov.cn/zhengce/content/201911/21/content_5454164.htm Erişim Tarihi: 10.09.2021

Triandis, H. (1995). New Directions in Social Psychology: Individualism and Collectivism. Boulder, CO: Westview Press.

Triandis, H., Bontempo, R., Villareal, M., Asai, M. \& Lucca, N. (1988). "Individualism and collectivism: crosscultural perspectives on self-ingroup relationships." Journal of Personality and Social Psychology. 54(2), 323-338. https://doi.org/10.1037/0022-3514.54.2.323

Tyrrell, D.A. \& Bynoe, M.L. (1966). "Cultivation of viruses from a high proportion of patients with colds." The Lancet. 287: 7428, 76-77. https://doi.org/10.1016/S0140-6736(66)92364-6

UNWTO. (2020). Tourism and coronavirus disease (COVID 19). https://www.unwto.org/international-tourism-andcovid-19 Erişim Tarihi: 09.09.2021.

Varotto, A. \& Spagnolli, A. (2017). "Psychological strategies to promote household recycling. A systematic review with meta-analysis of validated field interventions." Journal of Environmental Psychology. 51, 168-188. https://doi.org/10.1016/j.jenvp.2017.03.011

\section{Web Siteleri}

World Health Organization (WHO). (2016). Air Pollution. https://www.who.int/health-topics/air-pollution\#tab=tab_2 Erişim Tarihi: 18.08.2021

World Health Organization. (2020, Ocak 5). Pneumonia of unknown cause - China. https://www.who.int/emergencies/disease-outbreak-news/item/2020-DON229 Erişim Tarihi: 12.09.2021.

World Health Organization. (2021). WHO Coronavirus Dashboard. https://covid19.who.int/ Erişim tarihi: 09.09.2021.

Worldometer. (2020a). China population (live). https://www.worldometers.info/world-population/china-population/ Erişim Tarihi: 10.09.2021

Worldometer. (2020b). COVID-19 coronavirus outbreak. https://www.worldometers.info/coronavirus/\#countries Erişim Tarihi: 10.09 .2021

Wu, M. \& Wall, G. (2016). “中国家庭旅游之文献评述与研究启示(Chinese research on family tourism: review and research implications)." Journal of China Tourism Research. 12(3/4), 274-290. https://doi.org/10.1080/19388160.2016.1276873

Xu, H., Yan, C., Fu, Q., Xiao, K. \& Cheng, J. (2020) "Possible environmental effects on the spread of COVID-19 in China." Science of the Total Environment. 731, 139211. https://doi.org/10.1016/j.scitotenv.2020.139211

Ying, T. \& Wen, J. (2019). "Exploring the male Chinese tourists' motivation for commercial sex when travelling overseas: scale construction and validation." Tourism Management. 70, 479-490. https://doi.org/10.1016/j.tourman.2018.09.014

Zambrano-Monserrate M. A., Ruano, M. A. \& Alcalde, L. S. (2020). "Indirect Effects of COVID-19 on the Environment." Science of the Total Environment. 728, 1-4. https://doi.org/10.1016/j.scitotenv.2020.138813 
Zambrano-Monserrate, M.A. \& Ruano, M.A. (2019). "Does environmental noise affect housing rental prices in developing countries? Evidence from Ecuador.” Land Use Policy 87, 1-11. https://doi.org/10.1016/j.landusepol.2019.104059

Zambrano-Monserrate, M.A., Silva-Zambrano, C.A. \& Ruano, M.A. (2018). "The economic value of natural protected areas in Ecuador: a case of Villamil Beach National Recreation Area." Ocean \& Coastal Management 157, 193-202 https://doi.org/10.1016/j.ocecoaman.2018.02.020

Zhang, Q., Jiang, X., Tong, D., Davis, S.J., Zhao, H., Geng, G. \& Ni, R. (2017). "Transboundary health impacts of transported global air pollution and international trade." Nature 543, 705-709. https://doi.org/10.1038/nature21712

Zhong, P., Guo, S. \& Chen, T. (2020). "Correlation between travellers departing fromWuhan before the spring festival and subsequent spread of COVID-19 to all provinces in China." Journal of Travel Medicine. 27(3), 1-4. https://doi.org/10.1093/jtm/taaa036

Zhou, P., Yang, X.L. \& Wang, X.G. ve diğ. (2020). "A pneumonia outbreak associated with a new coronavirus of probable bat origin." Nature. 579, 270-273. https://doi.org/10.1038/s41586-020-2012-7 